\title{
Influence of Caecectomy on Digestibility of Amino Acids for Soybean, Canola and Sunflower Meals in Adult Cockerels
}

\author{
Ali Nouri-Emamzadeh ${ }^{1}$ and Akbar Yaghobfar ${ }^{2}$ \\ ${ }^{1}$ Department of Animal Science, Faculty of Agriculture, Islamic Azad University, Garmsar Branch, Garmsar, Iran \\ ${ }^{2}$ Animal Science Research Institute, Karaj-I.R. Iran
}

\begin{abstract}
The experiment was conducted to determine influence of caecectomy on digestibility quantities of amino acids for soybean (SBM), canola (CM), sunflower (SFM) meals in adult Rhode Island Red (RIR) cockerels with using conventional addition method (CAM) for $7 \mathrm{~d}$ : a 4-d adaptation and a 3-d experiment period on the basis of a completely randomized design with 4 replicates. In assayed meals, caecectomy decreased $(P<0.05)$ apparent digestibility quantities of amino acids, except for tyrosine, methionine and leucine for CM and arginine and valine for SFM in adult cockerels. The most decrement of apparent digestibility quantity was for phenylalanine (8.9\% decrement) in SBM and for cysteine $(14.5 \%$ and $22.7 \%$ decrement, respectively) in CM and SFM. Differences between intact and caecectomised cockerels were $(P<0.05)$ significant for true digestibility quantities of amino acids, except for threonine in SBM, serine and valine in CM and histidine, arginine, threonine and valine in SFM. The most difference in true digestibility quantity was for phenylalanine $(11.8 \%)$ in SBM and for cysteine (12.8 and 18\%, respectively) in CM and SFM. However, caecectomy decreased mean apparent and true digestibility of total amino acid in SBM (3.8 and 3.1\%, respectively), CM (3.1 and 3.0\%, respectively) and SFM (5.3 and $5.1 \%$, respectively) which this effect was greater for SFM. Therefore, the caecectomy is an effective method for increasing precision in measurements of the digestibility of amino acids for these meals in bioassays based on excreta collection in adult cockerels.
\end{abstract}

Key words: amino acid digestibility, caecectomy, canola meal, soybean meal, sunflower meal

J. Poult. Sci., 46: 19-24, 2009

\section{Introduction}

Soybean (SBM), canola (CM) and sunflower (SFM) meals are suitable protein sources in the diets of monogastric animals, especially poultry. However, the protein and amino acids quality of these protein sources could be depended to varieties, amounts of antinutrient factors, and type of oil extraction process (Lee et al., 1995; Vilamide and sanjuan, 1998). Therefore, more knowledge about nutritive value especially digestibility of amino acids in these vegetable protein sources produced in different countries aids to precision evaluation of the amounts used in poultry diets. Several methods to estimate the digestibility of amino acids have been developed by numerous authors (Payne et al., 1971; Sibbald, 1987; Ravindran and Bryden, 1999; Adeola, 2005). The majority of published digestibility quantities of amino acids for feedstuffs are based on the collection of excreta in intact adult birds or

Received: September 5, 2008, Accepted: November 6, 2008

Correspondence: Dr. A. Nouri-Emamzadeh, Department of Animal Science, Faculty of Agriculture, Islamic Azad University, Garmsar Branch, Postal Code 3581631167, Garmsar, Iran.

(E-mail: ali.nouriem@gmail.com) ileal digesta in chicks (Ravindran and Bryden, 1999; Parsons, 2002). But, bacteria present in the large intestine have an influence on digestibility measurements because they alter the composition and quantities of amino acids in the excreta, but have an insignificant effect on utilization of amino acids by the bird (Payne et al., 1971; Johns et al., 1986; Parsons, 1984). Surgical removal of the caeca, the major proportion of the large intestine, has been suggested to minimize bacterial effects on digestibility quantities of amino acids (Parsons, 1984; Johns et al., 1986) while small and non-significant effects have been reported (Longstaff et al., 1991; Ragland et al., 1999). However, information concerning the effect of caecectomy on digestibility of amino acids for SBM and especially CM and SFM is limited and discrepancy (Green et al., 1987; Angkanaporn et al., 1997; Ragland et al., 1999). Therefore, the objective of this experiment was to determine the influence of caecectomy on digestibility of amino acids for SBM, CM and SFM in adult cockerels.

\section{Materials and Methods}

\section{Feedstuffs, Birds, Design and Management}

The SBM, CM and SFM were obtained from a local oil seed crushing factory. Thirty two (16 intact and 16 
caecectomised) adult RIR cockerels (average age, 40 weeks; average weight, $2.9 \mathrm{~kg}$ ) placed in individual metabolic cages with fixed aluminum trays for separately excreta collection.

Caecectomy was performed when cockerels were 38 weeks of age. Prior to surgery, the cockerels selected to undergo the caecectomy were deprived of feed for $24 \mathrm{~h}$ and water for $12 \mathrm{~h}$. Caecectomy procedure was according with it described by Angkanaporn et al., 1997. The caeca were removed from most proximal to the ileal junction. The wound was sutured by a simple interrupted pattern using silk. After the surgery, the birds were kept in a warm $\left(28 \pm 2^{\circ} \mathrm{C}\right)$ house with ad libitum supply of the water and also, solid food was withheld for $24 \mathrm{~h}$. All birds were examined daily during the entire period of recovery. Their feed intake was comparable to it of intact birds within 10 days. Two weeks after the operation, the cockerels were used for experiment.

The experiment was carried out on the basis of a completely randomized design with 4 replicates; with using conventional addition method (CAM) included a 4-d adaptation period and a 3-d experiment period. In adaptation period, intact and caecectomised cockerels $a d$ libitum consumed each of test meals gradually mixed with a commercial basal diet, then after $24 \mathrm{~h}$ starvation, each of the test meals were ad libitum fed as single ingredient by those cockerels during 2-d of experiment period, and $24 \mathrm{~h}$ starvation in end of experiment period. Also during experiment, a group of eight (four intact and four caecectomised) adult cockerels were given no feed as negative controls to measure of the endogenous amino acid losses (EAAL). Feed intake was recorded and total excreta were collected from each bird during experiment period. The average temperature in the experiment house was $24 \pm 2^{\circ} \mathrm{C}$ with a lighting cycle of $16: 8 \mathrm{~h}$ (light: dark). Because of using adult cockerels and short period of the experiment, the cockerels' body weight average was changeless $(2.9 \mathrm{~kg})$ in end of experiment. The experiment and caecectomy procedure were according to the guidelines of Veterinary Faculty, Tehran University for the care and use of animals for scientific purposes.

\section{Analytical Methods}

The collected excreta were dried, weighed, and ground to pass a $1-\mathrm{mm}$ screen. The samples of the meals and excreta were analyzed for dry matter (DM), crude protein (CP) and neutral detergent fiber (NDF) according to AOAC (1990). For amino acid analysis, the samples were hydrolyzed with $6 \mathrm{~N} \mathrm{HCl}$ and then quantities of amino acids determined by high-performance liquid chromatography (HPLC) according to the procedure described by Siriwan (1993). Before acid hydrolysis, cysteine and methionine were oxidized with performic acid.

\section{Calculations}

Apparent and true digestibility quantities of amino acids (ADAA and TDAA) were calculated using the following formula:

$$
\begin{aligned}
& \operatorname{AAAD}(\%)=\frac{\mathrm{AA}_{\mathrm{c}}-\mathrm{AA}_{\mathrm{e}}}{\mathrm{AA}_{\mathrm{c}}} \times 100 \\
& \operatorname{TAAD}(\%)=\frac{\mathrm{AA}_{\mathrm{c}}-\mathrm{AA}_{\mathrm{e}}+\mathrm{EAAL}}{\mathrm{AA}_{\mathrm{c}}} \times 100
\end{aligned}
$$

$\mathrm{AA}_{\mathrm{c}}($ Amino Acid Consumed $)=$ feedstuff intake $\times$ feedstuff amino acid quantity $(\%)$

$\mathrm{AA}_{\mathrm{e}}($ Amino Acid Excreted $)=$ dry excreta weight $\times$ excreta amino acid quantity $(\%)$

$\mathrm{EAAL}=$ Endogenous Amino Acid Losses

Statistical Analysis

Statistical analysis of the data for determining influence caecectomy on apparent and true digestibility of amino acids each of the meals was accomplished using the GLM procedure of SAS software (SAS Institute, 1990) based on completely randomized design with 4 replications. The Duncan's test was used to elucidate differences between treatments means, with 0.05 level considered as significant. Results are reported as means and pooled standard error of mean (SEM).

\section{Results}

\section{Chemical and Amino Acid Compositions of the Meals}

Chemical and amino acid compositions of SBM, CM and SFM are shown in Table 1.

Caecectomy Influence on the Meals

Table 2 represents influence of caecectomy on apparent and true digestibility quantities of amino acids for SBM in

Table 1. Chemical and amino acid compositions of SBM, CM and SFM

\begin{tabular}{llll}
\hline \multicolumn{1}{c}{ Analysis } & SBM & CM & SFM \\
\hline DM $^{\mathrm{a}}(\%)$ & 92 & 93 & 95 \\
${\text { Crud Protein }(\%)^{\mathrm{b}}}^{\mathrm{c}}$ & 44 & 39 & 31 \\
NDF $(\%)^{\mathrm{b}}$ & 12.6 & 39.0 & 47.6 \\
Amino acid $(\%)^{\mathrm{b}}$ & & & \\
Aspartic acid & 3.15 & 1.87 & 1.19 \\
Glutamic acid & 9.6 & 9.93 & 8.05 \\
Serine & 3.47 & 2.73 & 1.96 \\
Glycine & 2.25 & 2.6 & 2.21 \\
Histidine & 1.37 & 1.14 & 0.93 \\
Arginine & 2.17 & 1.53 & 1.32 \\
Threonine & 3.63 & 2.8 & 2.08 \\
Alanine & 1.25 & 1.22 & 0.64 \\
Tyrosine & 1.84 & 1.25 & 0.93 \\
Valine & 2.27 & 2.02 & 1.52 \\
Methionine & 0.94 & 0.97 & 0.86 \\
Cysteine & 0.39 & 0.31 & 0.26 \\
Isoleucine & 2.02 & 2.13 & 0.91 \\
Leucine & 4.04 & 3.54 & 2.65 \\
Phenylalanine & 1.32 & 1.78 & 1.93 \\
Lysine & 3.4 & 2.17 & 1.73 \\
TAA & 43.11 & 37.99 & 29.17 \\
\hline
\end{tabular}

${ }^{\mathrm{a}} \mathrm{DM}=$ dry matter.

${ }^{\mathrm{b}}$ Based on $100 \%$ dry matter.

${ }^{\mathrm{c}} \mathrm{TAA}=$ total amino acids. 
Table 2. Influence of caecectomy on apparent and true digestibility quantities of amino acids for SBM in adult cockerels (based on $100 \% \mathrm{DM}$ )

\begin{tabular}{lccccccc}
\hline \hline \multirow{2}{*}{ Amino acid } & \multicolumn{3}{c}{ Apparent Digestibility } & & \multicolumn{3}{c}{ True Digestibility } \\
\cline { 2 - 3 } \cline { 6 - 7 } & Intact & Caecectomised & SEM $^{1}$ & & Intact & Caecectomised & SEM $^{1}$ \\
\hline Aspartic acid & $89.9^{\mathrm{a}}$ & $85.3^{\mathrm{b}}$ & 0.11 & & $91.4^{\mathrm{a}}$ & $87.2^{\mathrm{b}}$ & 0.11 \\
Glutamic acid & $88.3^{\mathrm{a}}$ & $85.9^{\mathrm{b}}$ & 0.30 & & $90.1^{\mathrm{a}}$ & $88.2^{\mathrm{b}}$ & 0.31 \\
Serine & $86.8^{\mathrm{a}}$ & $80.5^{\mathrm{b}}$ & 0.15 & & $90.4^{\mathrm{a}}$ & $86.8^{\mathrm{b}}$ & 0.23 \\
Glycine & $80.7^{\mathrm{a}}$ & $77.5^{\mathrm{b}}$ & 0.18 & & $84.3^{\mathrm{a}}$ & $81.9^{\mathrm{b}}$ & 0.22 \\
Histidine & $90.5^{\mathrm{a}}$ & $89.6^{\mathrm{b}}$ & 0.12 & & $91.7^{\mathrm{a}}$ & $90.3^{\mathrm{b}}$ & 0.12 \\
Arginine & $91.6^{\mathrm{a}}$ & $89.7^{\mathrm{b}}$ & 0.10 & & $93.7^{\mathrm{a}}$ & $92.6^{\mathrm{b}}$ & 0.16 \\
Threonine & $84.0^{\mathrm{a}}$ & $82.1^{\mathrm{b}}$ & 0.17 & & 89.1 & 88.9 & 0.27 \\
Alanine & $85.6^{\mathrm{a}}$ & $82.2^{\mathrm{b}}$ & 0.15 & & $88.2^{\mathrm{a}}$ & $84.8^{\mathrm{b}}$ & 0.18 \\
Tyrosine & $86.5^{\mathrm{a}}$ & $81.0^{\mathrm{b}}$ & 0.17 & & $88.8^{\mathrm{a}}$ & $83.6^{\mathrm{b}}$ & 0.19 \\
Valine & $85.2^{\mathrm{a}}$ & $79.4^{\mathrm{b}}$ & 0.17 & & $88.2^{\mathrm{a}}$ & $82.9^{\mathrm{b}}$ & 0.20 \\
Methionine & $79.8^{\mathrm{a}}$ & $75.0^{\mathrm{b}}$ & 0.24 & & $82.3^{\mathrm{a}}$ & $77.3^{\mathrm{b}}$ & 0.31 \\
Cysteine & $85.8^{\mathrm{a}}$ & $80.2^{\mathrm{b}}$ & 0.20 & & $88.9^{\mathrm{a}}$ & $86.4^{\mathrm{b}}$ & 0.25 \\
Isoleucine & $84.7^{\mathrm{a}}$ & $81.7^{\mathrm{b}}$ & 0.21 & & $85.0^{\mathrm{a}}$ & $84.3^{\mathrm{b}}$ & 0.21 \\
Leucine & $91.3^{\mathrm{a}}$ & $90.0^{\mathrm{b}}$ & 0.09 & & $93.3^{\mathrm{a}}$ & $91.6^{\mathrm{b}}$ & 0.12 \\
Phenylalanine & $69.6^{\mathrm{a}}$ & $60.7^{\mathrm{b}}$ & 0.31 & & $85.2^{\mathrm{a}}$ & $73.4^{\mathrm{b}}$ & 0.63 \\
Lysine & $92.0^{\mathrm{a}}$ & $90.7^{\mathrm{b}}$ & 0.08 & & $93.9^{\mathrm{a}}$ & $92.7^{\mathrm{b}}$ & 0.12 \\
MTAA & $85.8^{\mathrm{a}}$ & $82.0^{\mathrm{b}}$ & 0.14 & & $89.0^{\mathrm{a}}$ & $85.9^{\mathrm{b}}$ & 0.13 \\
\hline
\end{tabular}

${ }^{\mathrm{a}-\mathrm{b}}$ Means within a row with no common $(\mathrm{a}, \mathrm{b})$ superscript differ significantly $(P<0.05)$.

${ }^{1} \mathrm{SEM}=$ pooled standard error of mean.

${ }^{2}$ MTAA $=$ mean of total amino acids.

adult cockerels. Results indicated that apparent digestibility quantities of amino acids were less $(P<0.05)$ in caecectomised compare to intact cockerels. The caecectomy decreased apparent digestibility quantity of phenyalanine greater than other amino acids; this effect was $8.9 \%$ for phenyalanine. Mean apparent digestibility quantity of total amino acids for SBM in caecectomised $(82 \%)$ was $3.8 \%$ less $(P<0.05)$ than intact $(85.8 \%)$ cockerels. Differences between intact and caecectomised cockerels were $(P<0.05)$ significant for true digestibility quantities of amino acids, except for threonine. The most difference was $(P<0.05)$ for true digestibility quantity of phenylalanine $(11.8 \%)$. Mean true digestibility quantity of total amino acids for soybean meal in caecectomised and intact cockerels was 85.9 and $89 \%$, respectively which this significant $(P<0.05)$ difference was $3.1 \%$.

Influence of caecectomy on apparent and true digestibility quantities of amino acids for CM in adult cockerels are summarized in Table 3. The caecectomy decreased $(P<$ 0.05) apparent digestibility quantities of amino acids, except for tyrosine, methionine and leucine. The most significant effect was on apparent digestibility quantity of cysteine (14.5\% decrement). The caecectomy decreased $(P<0.05)$ mean apparent digestibility quantity of total amino acids of 86.8 to $83.7 \%$ (3.1\% decrement) for CM. True digestibility quantities of amino acids, except for serine and valine were differ $(P<0.05)$ between intact and caecectomised cockerels. The true digestibility quantity of cysteine had most difference $(12.8 \%)$ between intact and caecectomised cockerels. Mean true digestibility of total amino acids for $\mathrm{CM}$ in caecectomised cockerels $(85.6 \%)$ was $3.0 \%$ less $(P<0.05)$ than intact cockerels $(88.6 \%)$.

Table 4 represents influence of caecectomy on apparent and true digestibility quantities of amino acids for SFM in adult cockerels. Results indicated that differences between intact and caecectomised cockerels were $(P<0.05)$ significant for apparent digestibility quantities of amino acids, except for arginine and valine in SFM. The most difference $(22.7 \%)$ was $(P<0.05)$ for apparent digestibility quantity of cysteine. Mean apparent digestibility quantity of total amino acids for SFM in intact and caecectomised cockerels was 79.8 and $74.5 \%$ respectively which this difference $(5.3 \%)$ was significant $(P<0.05)$. True digestibility quantities of amino acids except for histidine, arginine, threonine and valine in SFM were less $(P<0.05)$ in caecectomised than intact cockerels. The caecectomy decreased true digestibility quantity of cysteine greater than other amino acids; this decrement was $18 \%$ for true digestibility of cysteine. Difference $(5.1 \%)$ between intact and caecectomised cockerels was $(P<0.05)$ significant for mean true digestibility quantity of total amino acids in SFM (87.2 and $82.1 \%$, respectively).

Influence of caecectomy on intakes of SBM, CM and SFM in adult cockerels was represented in Table 5. Caecectomy hadn't $(P>0.05)$ significantly effect on intake of the meals in adult cockerels.

\section{Discussion}

\section{Chemical and Amino Acid Compositions of the Meals}

The Dry matter, crude protein and NDF contents of SBM, CM and SFM used in this study approximately were according to those listed by NRC (1994). Amino acids 
Table 3. Influence of caecectomy on apparent and true digestibility quantities of amino acids for CM in adult cockerels (based on 100\% DM) Amino acid

\begin{tabular}{lccccccc}
\hline \hline \multirow{2}{*}{ Amino acid } & \multicolumn{3}{c}{ Apparent Digestibility } & & \multicolumn{3}{c}{ True Digestibility } \\
\cline { 2 - 3 } \cline { 6 - 7 } & Intact & Caecectomised & SEM $^{1}$ & & Intact & Caecectomised & SEM $^{1}$ \\
\hline Aspartic acid & $88.3^{\mathrm{a}}$ & $84.4^{\mathrm{b}}$ & 0.11 & & $90.0^{\mathrm{a}}$ & $86.5^{\mathrm{b}}$ & 0.11 \\
Glutamic acid & $91.7^{\mathrm{a}}$ & $89.4^{\mathrm{b}}$ & 0.08 & & $92.8^{\mathrm{a}}$ & $90.9^{\mathrm{b}}$ & 0.08 \\
Serine & $84.3^{\mathrm{a}}$ & $81.6^{\mathrm{b}}$ & 0.14 & & 87.0 & 87.0 & 0.18 \\
Glycine & $84.4^{\mathrm{a}}$ & $83.0^{\mathrm{b}}$ & 0.13 & & $86.0^{\mathrm{a}}$ & $85.0^{\mathrm{b}}$ & 0.13 \\
Histidine & $95.7^{\mathrm{a}}$ & $90.1^{\mathrm{b}}$ & 0.06 & & $95.7^{\mathrm{a}}$ & $90.2^{\mathrm{b}}$ & 0.06 \\
Arginine & $87.0^{\mathrm{a}}$ & $85.3^{\mathrm{b}}$ & 0.10 & & $89.1^{\mathrm{a}}$ & $87.1^{\mathrm{b}}$ & 0.11 \\
Threonine & $89.2^{\mathrm{a}}$ & $87.0^{\mathrm{b}}$ & 0.01 & & $89.2^{\mathrm{a}}$ & $87.0^{\mathrm{b}}$ & 0.10 \\
Alanine & $85.2^{\mathrm{a}}$ & $80.9^{\mathrm{b}}$ & 0.14 & & $86.7^{\mathrm{a}}$ & $82.4^{\mathrm{b}}$ & 0.14 \\
Tyrosine & 86.2 & 86.0 & 0.11 & & $88.4^{\mathrm{a}}$ & $87.9^{\mathrm{b}}$ & 0.12 \\
Valine & $84.0^{\mathrm{a}}$ & $83.0^{\mathrm{b}}$ & 0.13 & & 85.4 & 85.1 & 0.13 \\
Methionine & 90.5 & $90.4^{\mathrm{b}}$ & 0.08 & & $92.2^{\mathrm{a}}$ & $91.7^{\mathrm{b}}$ & 0.08 \\
Cysteine & $84.6^{\mathrm{a}}$ & $70.1^{\mathrm{b}}$ & 0.23 & & $85.5^{\mathrm{a}}$ & $72.7^{\mathrm{b}}$ & 0.22 \\
Isoleucine & $86.6^{\mathrm{a}}$ & $84.8^{\mathrm{b}}$ & 0.12 & & $88.3^{\mathrm{a}}$ & $85.0^{\mathrm{b}}$ & 0.11 \\
Leucine & 93.1 & 93.2 & 0.05 & & $94.5^{\mathrm{a}}$ & $94.2^{\mathrm{b}}$ & 0.06 \\
Phenylalanine & $72.2^{\mathrm{a}}$ & $64.7^{\mathrm{b}}$ & 0.31 & & $78.6^{\mathrm{a}}$ & $68.8^{\mathrm{b}}$ & 0.33 \\
Lysine & $86.9^{\mathrm{a}}$ & $85.3^{\mathrm{b}}$ & 0.10 & & $88.7^{\mathrm{a}}$ & $87.2^{\mathrm{b}}$ & 0.11 \\
MTAA & $86.8^{\mathrm{a}}$ & $83.7^{\mathrm{b}}$ & 0.15 & & $88.6^{\mathrm{a}}$ & $85.6^{\mathrm{b}}$ & 0.14 \\
\hline
\end{tabular}

${ }^{\mathrm{a}-\mathrm{b}}$ Means within a row with no common $(\mathrm{a}, \mathrm{b})$ superscript differ significantly $(P<0.05)$.

${ }^{1} \mathrm{SEM}=$ pooled standard error of mean.

${ }^{2}$ MTAA $=$ mean of total amino acids.

Table 4. Influence of caecectomy on apparent and true digestibility quantities of amino acids for SFM in adult cockerels (based on percentage DM)

\begin{tabular}{|c|c|c|c|c|c|c|}
\hline \multirow{2}{*}{ Amino acid } & \multicolumn{3}{|c|}{ Apparent Digestibility } & \multicolumn{3}{|c|}{ True Digestibility } \\
\hline & Intact & Caecectomised & SEM $^{1}$ & Intact & Caecectomised & SEM \\
\hline Aspartic acid & $83.1^{\mathrm{a}}$ & $79.7^{\mathrm{b}}$ & 0.29 & $88.8^{\mathrm{a}}$ & $84.3^{\mathrm{b}}$ & 0.47 \\
\hline Glutamic acid & $86.9^{\mathrm{a}}$ & $84.5^{\mathrm{b}}$ & 0.24 & $90.6^{\mathrm{a}}$ & $88.0^{\mathrm{b}}$ & 0.34 \\
\hline Serine & $71.6^{\mathrm{a}}$ & $65.3^{\mathrm{b}}$ & 0.54 & $84.1^{\mathrm{a}}$ & $80.0^{\mathrm{b}}$ & 0.66 \\
\hline Glycine & $66.3^{\mathrm{a}}$ & $57.1^{\mathrm{b}}$ & 0.68 & $73.8^{\mathrm{a}}$ & $63.7^{\mathrm{b}}$ & 0.84 \\
\hline Histidine & $84.9^{\mathrm{a}}$ & $83.7^{\mathrm{b}}$ & 0.30 & 86.8 & 86.3 & 0.32 \\
\hline Arginine & 75.3 & 75.0 & 0.43 & 80.8 & 80.7 & 0.58 \\
\hline Threonine & $84.3^{\mathrm{a}}$ & $79.6^{\mathrm{b}}$ & 0.31 & 93.1 & 91.1 & 0.75 \\
\hline Alanine & $76.6^{\mathrm{a}}$ & $70.7^{\mathrm{b}}$ & 0.48 & $85.7^{\mathrm{a}}$ & $77.6^{\mathrm{b}}$ & 0.80 \\
\hline Tyrosine & $86.6^{\mathrm{a}}$ & $80.4^{\mathrm{b}}$ & 0.24 & $93.7^{\mathrm{a}}$ & $87.9^{\mathrm{b}}$ & 0.53 \\
\hline Valine & 76.4 & 76.0 & 0.39 & 84.4 & 83.6 & 0.73 \\
\hline Methionine & $87.3^{\mathrm{a}}$ & $84.7^{b}$ & 0.22 & $92.5^{\mathrm{a}}$ & $88.4^{\mathrm{b}}$ & 0.45 \\
\hline Cysteine & $86.9^{\mathrm{a}}$ & $64.2^{\mathrm{b}}$ & 0.47 & $94.5^{\mathrm{a}}$ & $76.5^{b}$ & 0.89 \\
\hline Isoleucine & $69.3^{\mathrm{a}}$ & $66.2^{\mathrm{b}}$ & 0.52 & $74.6^{\mathrm{a}}$ & $70.4^{\mathrm{b}}$ & 0.63 \\
\hline Leucine & $83.1^{\mathrm{a}}$ & $80.9^{b}$ & 0.31 & $89.7^{\mathrm{a}}$ & $85.2^{\mathrm{b}}$ & 0.58 \\
\hline Phenylalanine & $75.2^{\mathrm{a}}$ & $72.7^{\mathrm{b}}$ & 0.41 & $92.2^{\mathrm{a}}$ & $88.9^{\mathrm{b}}$ & 1.20 \\
\hline Lysine & $82.9^{\mathrm{a}}$ & $72.2^{\mathrm{b}}$ & 0.59 & $90.9^{a}$ & $82.1^{\mathrm{b}}$ & 0.92 \\
\hline MTAA $^{2}$ & $79.8^{\mathrm{a}}$ & $74.5^{b}$ & 0.22 & $87.2^{\mathrm{a}}$ & $82.1^{\mathrm{b}}$ & 0.23 \\
\hline
\end{tabular}

${ }^{\mathrm{a}-\mathrm{b}}$ Means within a row with no common $(\mathrm{a}, \mathrm{b})$ superscript differ significantly $(P<0.05)$.

${ }^{1} \mathrm{SEM}=$ pooled standard error of mean.

${ }^{2}$ MTAA $=$ mean of total amino acids.

quantities of the meals approximately were greater compare to those reported in NRC (1994), but quantities of some amino acids in SBM, CM and SFM were consistent with those reported by Adeola O. (2005), Lee et al. (1995) and Villamide and Sanjuan (1998), respectively. However, factors such as variety type and conditions of culture and processing of oil seeds could affect compositions of the meals used in different studies.

Caecectomy Influence on the Meals

The results of present study which the caecectomy decreased digestibility quantities of amino acids for SBM, $\mathrm{CM}$ and SBM in adult cockerels support the opinion of 
Table 5. Influence of caecectomy on intake of SBM, CM and SFM in adult cockerels (g/2-d of experiment period)

\begin{tabular}{llcccc}
\hline \hline \multirow{2}{*}{ Oil Seed Meal } & \multicolumn{5}{c}{ Feed Intake } \\
\cline { 2 - 6 } & Intact & Caecectomised & SEM $^{1}$ & Mean & SEM \\
\hline SBM & 181.47 & 175.26 & 6.68 & 178.37 & 4.68 \\
CM & 169.8 & 160.54 & 6.91 & 165.17 & 4.87 \\
SFM & 152.25 & 144.1 & 7.96 & 148.17 & 5.53 \\
\hline
\end{tabular}

${ }^{\mathrm{a}-\mathrm{b}}$ Means within a row with no common $(\mathrm{a}, \mathrm{b})$ superscript differ significantly $(P<0.05)$.

${ }^{1}$ SEM: pooled standard error of mean.

significant microbial metabolism of undigested amino acids in the hindgut of intact birds (Parsons, 1984; Johns et al., 1986). Microbial activity in the caeca comprises both degradation of nitrogenous substrates and synthesis of microbial proteins; therefore the removal of the caeca results in increasing excretion of unabsorbed amino acids of dietary (Parsons, 1984) and endogenous origin (Green et al., 1987). Also, the results that the caecectomy caused intensive decrement in apparent and true digestibility of some amino acids especially phenylalanine for SBM and cysteine for CM and SFM could be related to less digestibility of the amino acids previous to caeca (Angkanaporn et al., 1997). Therefore, when excess amounts of amino acids are left undigested from small gut, it appears to be utilized by the caecal microorganisms. Also, more decrease of mean apparent and true digestibility of total amino acids in SFM (5.3 and 5.1\%, respectively) than those in SBM (3.8 and 3.1\%, respectively) and CM (3.1 and $3 \%$ ) could be due to greater NDF content and less protein quality in SFM than those in SBM and CM. High NDF quantity in SFM presents a high degree of lignification of cell wall which could decrease bioavailability of amino acids for enzymatic digestion prior to caeca (Villamide and Sanjuan, 1998) and increase microbial degradation of these undigested amino acids in caeca.

The correction for endogenous amino acid losses resulted in true digestibility quantities which were higher than the corresponding apparent digestibility quantities and didn't decrease significantly the differences of digestibility quantities of most amino acids between intact and caecectomised cockerels. In cockerels fed on SBM, adjustment of apparent to true digestibility eliminated only the effect of caecectomy on (true) digestibility quantity of threonine that could be due to greater excretion of endogenous threonine in caecectomised than intact cockerels. Also, insignificant difference between caecectomised and intact cockerels for true digestibility quantities of serine and valine in $\mathrm{CM}$ and for those of histidine and threonine in SFM could reflect greater endogenous excretion of these amino acids in caecectomised than intact cockerels. Also, in cockerels fed on CM, adjustment of apparent to true digestibility caused the significant effect of caecectomy on (true) digestibility quantity of tyrosine, methionine and leucine which was due to greater excretion of endogenous those in intact cockerels. However, the great- er effects of endogenous amino acid losses on apparent digestibility quantities of amino acids for SFM and CM could be attributed to approximately fewer intakes of the meals (Table 5) due to their higher hull and NDF content.

The results of present study are according to those presented by Johns et al. (1986) and Parsons (1986) that digestibility quantities of amino acids for protein sources could be decreased by caecectomy in adult cockerels. Parsons (1986) showed that this decrement was approximately $10 \%$ for true digestibility quantities of amino acids for meat meal. Ankanaporn et al. (1997) reported that caecectomy had no effect on the apparent digestibility of amino acids for SBM, except for histidine, lysine and arginine. A study on SBM and SFM indicated significant differences for apparent digestibility of some amino acids between intact and caecectomised cockerels (Green et al., 1987).

In present study, mean true digestibility quantity of total amino acids for SBM in caecectomised cockerels $(85.9 \%)$ was approximately less than it $(92.0 \%)$ represented by Angkanaporn et al. (1997). However, true lysine digestibility quantity $(92.7 \%)$ of SBM in caecectomised cockerels was consistent with it $(92.8 \%$, respectively) determined by Angkanaporn et al. (1997). There is a lack of published data about the digestibility of amino acids for CM and SFM measured by caecectomised birds. Green et al. (1987) indicated that true digestibility quantity of lysine for SFM was $83.4 \%$ in caecectomised cockerels. However, factors such as used bird type and age, experimental procedure, processing conditions of meals and feeding method probably could be responsible for the reported variations within the caecectomy effect on digestibility quantities of amino acids for a feedstuff.

In conclusion, the caecectomy decrease the microbial activities on digestibility of amino acids for SBM, CM and especially SFM in hindgut. Therefore, the caecectomy is an effective method for increasing precision in measurements of the digestibility of amino acids for these meals in bioassays based on excreta collection in adult cockerels.

\section{Acknowledgments}

This experiment was supported by Animal Science Research Institute. 


\section{References}

Adeola O. Metabolisable energy and amino acid digestibility of high-oil maize, low-phytate maize and low-phytate soybean meal for white Pekin ducks. British Poultry Science, 46: 607-614. 2005.

Angkanaporn K, Ravindran V and Bryden WL. Influence of caecectomy and dietary protein concentration on apparent excreta amino acid digestibility in adult cockerels. British Poultry Science, 38: 270-276. 1997.

Association of Official Analytical Chemists. Official Methods of Analysis, 15th Edition. Arlington, VA, AOAC. 1990.

Green S, Bertrand L, Duron JC and Maillard R. Digestibilities of amino acids in soybean, sunflower and groundnut meals, determined with caecectomised cockerels. British Poultry Science, 28: 643-652. 1987.

Johns DC, Low CK, Sedcole JR and James KAC. Determination of amino acid digestibility using caecectomised and intact adult cockerels. British Poultry Science, 27: 451-461. 1986.

Lee KH, Guang-Hai QI and Sim JS. Metabolizable energy and amino acid availability of full-fat seeds, meals, and oils of flax and canola. Poultry Science, 74: 1341-1348. 1995.

Longstaff M, McBain B and McNab JM. The antinutritive effect of proanthocyanidin-rich and proanthocya-free hulls from field beans on digestion of nutrients and metabolisable energy in intact and caecectomised cockerels. Animal Feed Science Technology, 34: 147-161. 1991.

National Research Council. Nutrient Requirements of Domestic Animals. Nutrient Requirements of Poultry, 9th revised edition. National Academy of press, Washington, D.C. 1994.

Parsons CM. Determination of digestible and available amino acids in meat meal using conventional and caecectomized cockerels or chick growth assays. British Journal of Nutrition, 56: 227-240. 1986.

Parsons CM. Digestibility and bioavailability of protein and amino acids. In Poultry Feedstuffs: Supply, Composition and Nutritive Value. (McNab. J. ed). CABI Publishing. Wallingford. Oxon. UK. 2002.

Parsons CM. Influence of caecectomy and source of dietary fiber or starch on excretion of endogenous amino acids by laying hens. British Journal of Nutrition, 51: 541-548. 1984.

Payne WL, Kifer RR, Snider DG and Combs GF. Studies of protein digestion in chicken. 1. Investigation of apparent digestibility fish meal protein using caecectomised adult male chicken. Poultry Science, 50: 143-150. 1971.

Ragland D, Thomas CR, Elkin RG, Shafer DJ and Adeola O. The influence of cecectomy on metabolizable energy and amino acid digestibility of feedstuffs for white Pekin ducks. British Poultry Science, 78: 707-713. 1999.

Ravindran V and Bryden WL. Amino acid availability in poultry: In vitro and in vivo measurements. Australian Journal of Agricultural Research, 50: 889-908. 1999.

SAS Institute. SAS Stat User's Guide Release 6.08. SAS Institute Inc., Cary. NC. 1990.

Sibbald IR. Estimation of bioavailable amino acids in feedstuffs for poultry and pigs: A review with emphasis on balance experiments. Canadian Journal of Animal Science, 67: 221300. 1987.

Siriwan P, Bryden WL, Mollah Y and Annison EF. Measurement of endogenous amino acid losses in poultry. British Poultry Science, 34: 939-949. 1993.

Vilamide MJ and Sanjuan LD. Effect of chemical composition of sunflower seed meal on its true metabolizable energy and amino acid digestibility. Poultry Science, 77: 1884-1892. 1998. 